\title{
Changes in Ripening Associated Biochemical and Enzymatic Characteristics of Late Season Mango (Mangifera indica, L.) of Bangladesh
}

\author{
M. A. Hossain* \\ Department of Biochemistry and Molecular Biology, University of Rajshahi, Rajshahi-6205, \\ Bangladesh
}

Received 2 April 2016, accepted in final revised form 15 July 2016

\begin{abstract}
Mango is the most important fruit in Bangladesh because of its great utility, characteristic flavor, pleasant aroma and nutritional values, but short shelf life limits its export potentiality to earn foreign currency. To identify the key factors associated with ripening process of late season mango, we comparatively analyzed the unripe (mature green) and ripe fruit of late season mango (Ashwina variety). The starch, reducing sugar (RS), vitamin-C and total titratable acidity (TA) were significantly higher at the unripe stage than that at the ripening stage. The total sugar (TS), non-reducing sugar (NRS), total soluble solid (TSS) and total phenol (PC) were found to be lower at unripe stage than that of the levels of respective parameters at ripen stage. Enzymatic analysis showed that the activity of $\beta$-hexosaminidase increased 13-folds at ripen stage than that at mature stage, while the activity of $\alpha$ mannosidase, polyphenol oxidase, $\beta$-galactosidase and $\beta$-glucanase increased moderately; again amylase and invertase activity decreased, suggesting that $\beta$-hexosaminidase is a biomarker enzyme that predominantly associated with the ripening of Ashwina mango.
\end{abstract}

Keywords: Mangifera indica; Biochemical characteristics; Ripening associated enzymes; Fruit softening.

(C) 2016 JSR Publications. ISSN: 2070-0237 (Print); 2070-0245 (Online). All rights reserved. doi: http://dx.doi.org/10.3329/jsr.v8i3.27218 J. Sci. Res. 8 (3), 387-398 (2016)

\section{Introduction}

The mango (Mangifera indica L.) is the most important fruit in Bangladesh because of its great utility, characteristic flavor, pleasant aroma and nutritional value, being consigned as such when ripe. Both ripe and raw fruits are used to make variety of chemical products (juice, chutney, jelly, etc.). For these reasons it is acknowledged as the king of fruits not only in Bangladesh but also in the South-East Asian countries. Mango has medium calorific and high nutritional values especially carbohydrate [1]. It is also rich in vitamins, minerals and total soluble solid (TSS) and therefore can prevent many deficiency diseases

\footnotetext{
Corresponding author: mahossain95@hotmail.com
} 
[2]. Malnutrition and under-nutrition have now become an alarming for the people of the third world country affecting their economic and physical development. Protein energy malnutrition and vitamin deficiencies are the most serious nutritional disorders in low income groups. Due to these deficiencies under weights and high mortality are found in pre-school children and infants, which cause mental and physical retardation in the population [3]. The minimum dietary requirement of fruit per day person is $115 \mathrm{~g}$, where as our availability is only $30-35 \mathrm{~g}$, which is much lower than recommended daily allowance. The per capita availability of fruit is further reduced due to high level of postharvest losses. Post-harvest losses can be reduced considerably by applying improved technologies and prolonging the shelf life of fruit. Being a commercially important and highly perishable fruit, efforts to check mangoes post-harvest losses should get top priority. A considerable quantity (30-35\%) of fruit goes waste through post-harvest decay [4]. The postharvest life of any fruit consists of ripening and senescence. The ripening and subsequent senescence are the sum of a number of post-harvest chemical changes. The prolonging storage life of a fruit means slowing down biochemical processes leading ripening and stopping the degradation as well as fermentation changes that cause senescence after ripening. Hence it is necessary to understand the post-harvest physiology of mango in order to develop and apply adequate post-harvest technologies. The physicochemical process during and after ripening of fruit also needs to be studied extensively for the development of proper storage methods. Several authors [5] studied the post-harvest losses and physiological changes in mango. But such experimental studies have not been carried out for Ashwina variety of mangoes.

The earlier studies on mango fruit softening mainly focused on the post harvest physiology, especially, organic acid metabolism, fruit flavors volatiles, overall composition and gross changes in total pectin during ripening. However, detailed studies on the quantitative and qualitative changes of biochemical parameters during fruit ripening or textural softening have not been carried out in Ashwina variety of mangoes and the in vivo hydrolysis by corresponding hydrolases in relation to textural softening have not been carried out. The aim of the present study was to understand the factors contributing to the textural changes in relation to carbohydrate degradation by respective hydrolases during ripening of mango. Furthermore, the study was undertaken to find out the effective factors for increasing the shelf life of mango fruits (Ashwina variety) to minimize the post harvest loss.

\section{Experimental}

\subsection{Sample collection}

Ashwina variety of mango at full mature and ripen stages was collected from Fruit Research Institute, Rajshahi. After discarding the disease associated and injured ones, the mangoes were divided into two groups, unripe (mature green) and full ripe. They were finally stored at $-20^{\circ} \mathrm{C}$ for analysis. Unless stated otherwise, all the reagents, synthetic and 
other substrates used for performing the experiments were from Sigma-Aldrich and CarlRoth GmbH, Germany.

\subsection{Extraction of fruit juice from mango}

About $50 \mathrm{~g}$ of fruit tissue was homogenized with a blender and filtered through two layers of muslin cloth. The filtrate was then centrifuged for $20 \mathrm{~min}$ at $8,000 \mathrm{~g}$ at $4{ }^{\circ} \mathrm{C}$ and the clear supernatant was collected.

\subsection{Total soluble solids (TSS) and titratable acidity (TA)}

TSS was determined according to the method as described by Mazumdar et al. using Digital-Bench-Refractometer (Range 0-32\%) [6]. An appropriate quantity of each sample was placed on the prism-plate of the refractometer and the reading appearing on the screen was directly recorded as total soluble solids $\left({ }^{\circ}\right.$ Brix). Titratable acidity (TA) was determined according to the method as described by Hortwitz [7]. $10 \mathrm{~mL}$ of crude extract was taken in a beaker and titrated with $0.1 \mathrm{~N} \mathrm{NaOH}$ after adding 2-3 drops of phenolphthalein as an indicator. The percentage $(\%)$ of citric acid was calculated from the following formula:

Titratable Acidity $(\%)=\frac{\text { Volume of } 0.1 \mathrm{~N} \mathrm{NaOH} \times \text { Factor }(0.0064)}{\text { Volume of sample used }} \times 100$

\subsection{Vitamin C}

Approximately 2-3 g of mango flesh was cut into small pieces and homogenized well with $20 \mathrm{~mL}$ of $3 \%$ meta-phosphoric acid and filtered through double layer of muslin cloth. The filtrate was centrifuged at 3,000 $\mathrm{g}$ for $10 \mathrm{~min}$ and the clear supernatant was titrated with 2, 6-dichlorophenol indophenol solution as described elsewhere [8]. The amount of vitamin $\mathrm{C}$ in the extract was determined by comparing with the titration curve of standard vitamin $\mathrm{C}$ solution. Result was expressed as $\mathrm{mg} / 100 \mathrm{~g}$ of fresh fruit.

\subsection{Starch content}

The starch content of the mango flesh was determined by the Anthrone method [9]. $2 \mathrm{~g}$ of mango was cut into small pieces and homogenized well in $20 \mathrm{~mL}$ water. It was then filtered through double layer of muslin cloth. Excess ethanol was added to the filtrate to precipitate the polysaccharide, mainly starch. After keeping overnight at $4{ }^{\circ} \mathrm{C}$, the precipitate was collected by centrifugation at 3,000 $\mathrm{g}$ for $15 \mathrm{~min}$. The precipitate was heated to dryness and dissolved in $40 \mathrm{~mL}$ of $1 \mathrm{M} \mathrm{HCl}$ and then heated at $70^{\circ} \mathrm{C}$ for few min. It was then transferred to a volumetric flask and diluted to $100 \mathrm{~mL}$ with $1 \mathrm{M} \mathrm{HCl}$. Aliquot of $1 \mathrm{~mL}$ of the extract of each sample was pipetted into test tubes and $4 \mathrm{~mL}$ of the 
anthrone reagent was added to each test tube and mixed well. The tubes were placed in a boiling water bath for $10 \mathrm{~min}$ and cooled. A blank reagent was prepared by using $1 \mathrm{~mL}$ of water and $4 \mathrm{~mL}$ of anthrone reagent in a test tube and treated similarly. The absorbance of the blue-green solution was measured at $680 \mathrm{~nm}$ in UV-VIS spectrophotometer (U-1800, Hitachi, Japan). The amount of starch present in mango flesh was calculated from the standard curve of different concentrations of glucose and expressed as $\mathrm{g} / 100 \mathrm{~g}$ of fresh fruits.

\subsection{Total sugar (TS), reducing sugar (RS), non-reducing sugar (NRS) and phenol content (PC)}

$2 \mathrm{~g}$ of mango flesh was cut into small pieces and plunged into $20 \mathrm{~mL}$ of boiling ethanol for 5-10 min. After cooling, it was crushed thoroughly in a mortar with a pestle. The homogenate was filtered through two layers of muslin cloth and re-filtered through a Whatman no-41 filter paper. The extract was evaporated to dryness over a steam bath and subsequently cooled. The residues were dissolved in $100 \mathrm{~mL}$ of distilled water and the resulting solution was used as flesh extract (sample stock) for the estimation of total sugar (TS), reducing sugar (RS) and phenol content (PC).

\subsubsection{TS}

TS content of mango was determined colorimetrically by the anthrone method [9]. Aliquot of $1 \mathrm{~mL}$ of the flesh extract was pipetted out into three test tubes and $4 \mathrm{~mL}$ of anthrone reagent was added to each tube and mixed well. The test tubes were placed in a boiling water bath for $10 \mathrm{~min}$. After cooling, the absorbance was measured at $680 \mathrm{~nm}$ against a blank reagent. The TS in the sample tubes were determined from the standard curve prepared using different concentrations of glucose and expressed as $\mathrm{g} / 100 \mathrm{~g}$ of mango flesh.

\subsection{2. $R S$}

RS content of the mango was determined by dinitrosalicylic acid (DNS) method [10]. Aliquot of $3 \mathrm{~mL}$ of the flesh extract was pipetted into 3 test tubes and $3 \mathrm{~mL}$ of DNS reagent was added to each of this solution and mixed well. The test tubes were heated for $5 \mathrm{~min}$ in a boiling water bath. After coloration $1 \mathrm{~mL}$ of $40 \%$ Rochelle salt was added when the content was still warm. The test tubes were then cooled under a running tap water. The absorbance of the solution was measured at $575 \mathrm{~nm}$ in a colorimeter against a blank reagent. The amount of RS present in test tubes were calculated from the standard curve of glucose and expressed as g/100 $\mathrm{g}$ of mango flesh. 


\subsubsection{NRS}

NRS content of the mango pulp was calculated from the following formula [11].

NRS $(\%)=\operatorname{TS}(\%)-\operatorname{RS}(\%) \times$ Factor $(0.95)$

\subsection{4. $P C$}

PC was estimated by the Folin-ciocalteau reagent method [12]. Aliquot of $1 \mathrm{~mL}$ was pipetted into 3 test tubes and $1 \mathrm{~mL}$ of Folin-ciocalteau reagent was added. After $3 \mathrm{~min}, 2$ $\mathrm{mL}$ of $20 \% \mathrm{Na}_{2} \mathrm{CO}_{3}$ solution was added to each tube. The contents were mixed thoroughly, and the tubes were placed in boiling water bath for 2 min. After cooling, the absorbance was measured at $650 \mathrm{~nm}$ against a blank reagent. A standard curve was plotted using different concentrations of catechol. From this standard curve, the concentration of phenols in the test sample was determined and expressed as $\mathrm{mg} / 100 \mathrm{~g}$ of mango flesh.

\subsection{Enzymatic analysis}

The activity of amylase, invertase, polyphenol oxidase, $\beta$-glucanase, $\beta$-galactosidase, $\alpha$ mannosidase, and $\beta$-hexosaminidase was assayed according to the following protocols:

\subsubsection{Amylase activity assay}

Amylase activity was assayed according to the method described by Jayaraman [9]. 1\% starch solution was used as substrate. The enzyme activity was measured by estimating the release of maltose calculated from the standard curve prepared with different concentrations of maltose. One unit of enzyme activity is defined as the amount of enzyme required to release $1 \mathrm{mg}$ of maltose per min at $37^{\circ} \mathrm{C}$.

\subsubsection{Invertase activity assay}

Invertase activity was assayed by the modified method as described by Mahadevan and Sridhar [13]. Sucrose was used as substrate. The invertase activity was measured by estimating the release of glucose calculated from the standard curve prepared with different concentrations of glucose. One unit of enzyme activity is defined as the amount of enzyme required to release $1 \mathrm{mg}$ of glucose per min at $37^{\circ} \mathrm{C}$.

\subsubsection{Polyphenol oxidase (PPO) activity assay}

The polyphenol oxidase (PPO) activity in mango fruit was measured as described by Mahadevan and Sridhar [13]. In this method, catechol was used as substrate. One unit of enzyme activity was defined as a change in absorbance of 0.001 per min per $\mathrm{mL}$ of 
enzyme extract. PPO activity was determined using a spectrophotometric method based on an initial rate of increase in absorbance at $495 \mathrm{~nm}$. Aliquot of $2 \mathrm{~mL}$ of the crude extract and $3 \mathrm{~mL}$ of $0.1 \mathrm{M}$ phosphate buffer $\mathrm{pH} 6.0$ were taken in a cuvette. The content was mixed by inverting the cuvette and placed in a spectrophotometer set at $495 \mathrm{~nm}$. Then the absorbance was adjusted to zero. The cuvette was removed and $1 \mathrm{~mL}$ of catechol was added and quickly mixed by inversion. The cuvette was placed in the spectrophotometer and the change in absorbance at $495 \mathrm{~nm}$ was measured for 3 min.

\subsection{4. $\beta$-Glucanase activity assay}

At first $50 \mu \mathrm{L}$ of substrate ( $p$-nitrophenyl- $\beta$-glucopyranoside) was taken in an eppendroff tube. Then $100 \mu \mathrm{L}$ of $100 \mathrm{mM}$ phosphate buffer ( $\mathrm{pH}$ 6.0) was added. Then $50 \mu \mathrm{L}$ crude extract from mango was added to the mixture. The mixture was then incubated at $37^{\circ} \mathrm{C}$ for an hour. After incubation $1.3 \mathrm{~mL}$ of glycine- $\mathrm{NaOH}$ buffer $(\mathrm{pH} 10.5)$ was added to stop the reaction. The amount of $p$-nitrophenol released from $p$-nitrophenyl- $\beta$-glucopyranoside was measured by spectrophotometric method at $420 \mathrm{~nm}$. One unit of enzyme activity is defined as the amount of enzyme releasing $1 \mu \mathrm{mol}$ of $p$-nitrophenol per min at $37^{\circ} \mathrm{C}$.

\subsection{5. $\beta$-Galactosidase, $\alpha$-mannosidase, and $\beta$-hexosaminidase activity assay}

Enzyme activities of four glycosidases were assayed by estimating the release of $p$ nitrophenol according to the method described by Hossain [14,15]. The $50 \mu \mathrm{L}$ of $100 \mu \mathrm{M}$ substrate ( $p$-nitrophenyl- $\alpha$-mannopyranoside / $p$-nitrophenyl $\alpha$-glucopyranoside / $p$ nitrophenyl- $\beta$-D-galactopyranoside / $p$-nitrophenyl- $\beta$-hexosaminide) was aliqouted into four separate eppendorf tubes and $100 \mu \mathrm{L}$ of $100 \mathrm{mM}$ phosphate buffer (pH 6.0) was added to each tube. A $50 \mu \mathrm{L}$ crude extract was then added to each tube and incubated at $37^{\circ} \mathrm{C}$ for an hour. To stop the reaction, $1.3 \mathrm{~mL}$ of glycine- $\mathrm{NaOH}$ buffer $(\mathrm{pH} 10.5)$ was added to each tube. The amount of $p$-nitrophenol released from substrates was measured by spectrophotometric method at $420 \mathrm{~nm}$. One unit of enzyme activity is defined as the amount of enzyme required to release $1 \mathrm{nmol}$ of $p$-nitrophenol per min at $37^{\circ} \mathrm{C}$.

\section{Results and Discussion}

Table 1 represents the changes in biochemical parameters of ripe and unripe mango (Ashwina) fruits just after harvest.

\subsection{TSS and TA}

At mature (unripe) stage, the TSS content was 5\%. On the contrary at ripen stage, the TSS increased almost 3-fold (Table 1). Similar results were reported by Krishnamurty and Subramanyam [5]. This 3-fold increase in TSS may be due to the hydrolysis of starch to sucrose at the ripen stage $[5,16]$. At mature (unripe) stage, the TA content was $1.06 \%$ 
while it reduced to about one third at ripen stage. These results agreed with that reported by Jha et al. [17] which suggested that acidity of mango-flesh decreased significantly during ripening.

Table 1. Biochemical parameters of unripe and ripe Ashwina mango just after harvest.

\begin{tabular}{|c|c|c|c|c|c|c|c|c|}
\hline Sample & $\begin{array}{l}\text { TA } \\
(\%)\end{array}$ & $\begin{array}{l}\text { VC } \\
(\mathrm{mg} / 100 \mathrm{~g}\end{array}$ & $\begin{array}{l}\text { TSS } \\
(\mathrm{g} \%)\end{array}$ & $\begin{array}{l}\text { TS } \\
(\mathrm{g} \%)\end{array}$ & $\begin{array}{l}\text { RS } \\
(\mathrm{g} \%)\end{array}$ & $\begin{array}{l}\text { NRS } \\
(\mathrm{g} \%)\end{array}$ & $\begin{array}{l}\text { Starch } \\
(\mathrm{g} \%)\end{array}$ & $\begin{array}{l}\mathrm{TP} \\
(\mathrm{g} \%)\end{array}$ \\
\hline Unripe & $1.06 \pm 0.02$ & $241 \pm 12$ & $5 \pm 0.5$ & $5.6 \pm 0.5$ & $3.04 \pm 0.3$ & $2.43 \pm 0.07$ & $12 \pm 0.5$ & $0.83 \pm 0.05$ \\
\hline Ripe & $0.49 \pm 0.01$ & $85.5 \pm 9.1$ & $14 \pm 1.3$ & $22 \pm 0.96$ & $0.5 \pm 0.01$ & $20.43 \pm 2.0$ & $4.5 \pm 0.03$ & $7.28 \pm 0.7$ \\
\hline
\end{tabular}

\subsection{Vitamin C content}

At mature (unripe) stage, the vitamin-C content was $241(\mathrm{mg} / 100 \mathrm{~g})$ whereas at ripen stage, it reduced to about one third compared to unripe one (Table 1). The values obtained in this study for unripe and ripe mangoes were higher than that reported for Fazli and Langra cultivars of India [5]. This indicated that vitamin-C content decreased significantly with the ripening of mango.

\subsection{Starch content}

The data in Table 1 demonstrates that the starch content at mature (unripe) stage is 3 times higher than that at ripen stage. It was also found that polysaccharide content decreased remarkably from mature stage to ripen stage. This might be due to hydrolysis of polysaccharide. These results were consistent with the reported value [17]. It is also reported that starch is the main carbohydrate present in mature green pulp, which is being hydrolyzed by some enzymes such as $\alpha$ - and $\beta$-amylases [18].

\subsection{TS, RS, NRS and PC}

Carbohydrates have two major biological functions in plant. Glucose and starch serve as important source of energy for vital activities. Cellulose and lignin serve as structural elements. At ripen stage, the TS content was four times higher than that at unripe stage (Table 1). These results are consistent with that reported by Jha et al. [17]. Above results differ to some extent from the findings for Fazli and Langra produced in India [5]. At mature stage, the RS content was 6-fold higher than that at ripen stage indicating that the RS content decreased significantly with the ripening of mango due to the hydrolysis of polysaccharide. At ripen stage, the NRS content was about 8 -fold higher than that mature stage, indicating that the NRS content increased significantly with the ripening of mango (Table 1). At mature (green) stage, the total PC was 9-fold lower than that at ripen stage. These results are similar to that reported by Jha et al. [17]. 
Table 2 represents the changes in the activity of amylase, invertase, polyphenol oxidase, $\beta$-galactosidase, $\beta$-hexosaminidase, $\beta$-glucanase, and $\alpha$-mannosidase of ripe and unripe mango (Ashwina) fruits just after harvest.

\subsection{Activity of amylase}

At mature stage, the activity of amylase in the mango was found to be two-folds higher than that at ripen stage (Table 2). Since at ripen stage, the starch content was found to decrease, the amylase activity also logically decreased. Amylase, an enzyme having physiological, commercial and historical significance, also called diastase. Two types of amylase are recognized. $\beta$-amylase (in plants and bacteria) can only remove the terminal two glucose molecules in each catalytic cycle, Payven et al. were the first to become aware of enzymatic starch hydrolysis [19]. They found that malt extract converted starch to sugar. Starch is the principal storage carbohydrate in plant cells, made up of amylose and amylopectin.

Table 2. Enzymatic activity assay of unripe and ripe of Ashwina mango just after harvest.

\begin{tabular}{llllllll}
\hline Sample & $\begin{array}{l}\text { Amylase } \\
(\mathrm{Unit} / \mathrm{mL})\end{array}$ & $\begin{array}{l}\text { Invertase } \\
(\mathrm{Unit} / \mathrm{mL})\end{array}$ & $\begin{array}{l}\mathrm{PPO} \\
(\mathrm{Unit} / \mathrm{mL})\end{array}$ & $\begin{array}{l}\beta \text {-Gal } \\
(\mathrm{Unit} / \mathrm{mL})\end{array}$ & $\begin{array}{l}\beta \text {-Hex } \\
(\mathrm{Unit} / \mathrm{mL})\end{array}$ & $\begin{array}{l}\beta \text {-Glu } \\
(\text { Unit/mL) }\end{array}$ & $\begin{array}{l}\alpha \text {-Man } \\
(\mathrm{Unit} / \mathrm{mL})\end{array}$ \\
\hline Unripe & $0.12 \pm 0.02$ & $0.0134 \pm 0.00$ & $84 \pm 9$ & $367 \pm 23$ & $98 \pm 11$ & $92 \pm 06$ & $84 \pm 07$ \\
Ripe & $0.053 \pm 0.01$ & $0.0053 \pm 0.00$ & $276 \pm 13$ & $1683 \pm 51$ & $1361 \pm 65$ & $312 \pm 31$ & $416 \pm 39$ \\
\hline PPO = Polyphenol oxydase; $\alpha$-Man $=\alpha$-Mannosidase; $\beta$-Gal $=\beta$-Galactosidase; $\beta$-Glu = $\beta$-Glucanase; \\
$\beta$-Hex = $\beta$-Hexosaminidase
\end{tabular}

\subsection{Activity of invertase}

The activity of invertase at mature green stage was found to be above 2 -folds relative to that at ripen stage (Table 2). Consequently, the sucrose hydrolysis rate is lower at ripen stage. The enzyme occurs widely in plant, microbial and animal sources. Invertase plays an important role in the hydrolysis of sucrose to glucose and fructose in higher plants, especially in the storage organs. Sucrose serves as an important carbohydrate in pants; especially in storage organs such as tuber, root and seed, sucrose is a readily degradable source of energy [20].

\subsection{Activity of PPO}

The activity of PPO at mature (green) stage was found to be about 3 times lower than that at ripen stage. A positive correlation was observed between the increasing PPO and total $\mathrm{PC}$ at ripening stage. PPO is an oxidative enzyme, which catalyzes the oxidation of phenolic substrates mainly due to enzymatic browning [22]. They catalyze the oxidation of phenolic compounds to $o$-quinone, which polymerize to form undesirable pigments [23]. Physiological disorders that cause discoloration of pulp and peel in mango fruit usually occur when they are stored at temperatures less than $13^{\circ} \mathrm{C}$. It has been shown that 
PPO may be involved with physiological disorders of mango [21]. Tropical mango fruit is popular worldwide for its tasty fleshy pulp. However, little is known on the properties of PPO in mango pulp. Present study indicates that PPO activity increases with fruit softening [15].

\subsection{Activity of $\beta$-glucanase}

The $\beta$-glucanase activity of Ashwina cultivar at mature (unripe) stage was found to be about 3 times less than that found at ripe stage. It clearly indicated that $\beta$-glucanase (cellulase) activity drastically increased during the onset of ripening. Cellulase is a multienzyme system composed of several enzymes; endo-glucanase (EC 3.2.1.4), exoglucanase (EC 3.2.1.91) and glucosidase (EC 3.2.1.21). Endoglucanase hydrolyses the $\beta$ 1,4-linked glucose residues at random positions. Exo-glucanase breaks the bonds at nonreducing end of the chain, producing glucose or cellobiose (dimers of $\beta$-1, 4-linked glucose), whereas $\beta$-glucosidase splits cellobiose into glucose molecules. Cellulase levels in unripe fruit were generally low and increased dramatically during ripening [24]. The loss of firmness, climacteric rise of respiration and ethylene evolution in ripening fruit was directly correlated with marked increase in cellulase activity [25,26]. Cellulase has been implicated in softening process in tomato [27]. Cellulase activity was reported in several Indian mango cultivars [28], which increased during ripening especially in Alphonso. The progressive textural loss in 'keitt' mango was attributed to marked increase in cellulase activity [29]. This enzyme plays a significant role in onset of ripening.

\subsection{Activity of $\beta$-galactosidase}

The $\beta$-galactosidase activity of ripe mango is more than 4 times higher than that of unripe mango (Table 2). The results obtained in this study are consistent with that found in literature [15]. The release of arabinosyl and galactosyl residues from pectic side chains is also an important event involved in fruit softening [30,31], which is related to the activity of $\beta$-galactosidases. It is also called $\beta$-gal, this class of cell wall degrading enzymes belongs to the glycosyl hydrolase enzymatic group, which is characterized by its ability to hydrolyse $\beta$-D-galactosyl residues from the non-reducing terminals of $\beta$-D-galactosides [32].

\subsection{Activity of $\beta$-hexosaminidase}

$\beta$-hexosaminidase $(\beta$-Hex) activity of ripe mango increased approximately 13 -folds in comparison with that of mature green fruit which is supported by the results obtained by Hossain et al. [15]. This enzyme is a member of the glycosyl hydrolase family 20 (GH20) that hydrolyses non-reducing terminal monosaccharide residues of $\beta-N$ acetylgalactosaminides and $\beta$-N -acetylglucosaminides [33]. The $\beta$-Hex was also reported 
at high levels during the ripening of many fruits including capsicum [34]. It could be a key enzyme responsible for fruit softening [15].

\subsection{Activity of a-mannosidase}

Activity of $\alpha$-mannosidase at mature green stage was found to be 5 times lower than that found at ripen stage of Ashwina cultivar, clearly indicating that $\alpha$-mannosidase was present at high levels during the onset of ripening. Among glycosidases, the prominent enzymes found in ripe fruit were $\alpha$-mannosidase, $\beta$-hexosaminidase and $\alpha$ - and $\beta$ galactosidases [14,34]. $\alpha$-Mannosidase documented in very few fruit systems, acts on short chain oligomers ( 8-10) of mannose units present either as glycoprotein, glycolipid or hetero-/homopolysaccharides. This enzyme partially degrades the pectic and hemicellulosic components of the cell wall and is possibly related to the breakdown of polysaccharides. Increased activity of $\alpha$-mannosidase during ripening has been reported in tomato, grape, muskmelon, pear and watermelon [14,35-38].

\section{Conclusion}

Softening during ripening is an important process in most fruits, which is due to changes in cell wall composition. The starch, reducing sugar, vitamin-C and total TA were higher at the unripe stage than in ripen mango while the TS, NRS, TSS and total PC were lower at the unripe stage than at the full ripen stage. Ripening of mango is characterized by changes such as hydrolysis of starch, a concomitant increase in TS, NRS, TSS, total PC and a decrease in TA and vitamin-C. Ripening is also characterized by rapid and extensive softening of fruit, which correlates positively with an increase in the activity of most of the carbohydrate hydrolases and with the solubilization of respective polysaccharides. From this study it was observed that the activity of $\beta$-hexosaminidase increased 13 times at ripen stage; and PPO, $\beta$-galactosidase, $\alpha$-mannosidase and $\beta$-glucanase increased moderately; on the other hand, the activities of amylase, invertase decreased. These results indicated that $\beta$-hexosaminidase is predominantly associated with ripening of mango fruits. This finding may pave the way to adopt an effective strategy or approach for enhancing the shelf life of mango fruits to minimize the postharvest loss. To increase the shelf life of Ashwina variety of mango, it is recommended to identify the gene of $\beta$ hexosaminidase enzyme and to generate transgenic plants where $\beta$-hexosaminidase is knocked down or knocked out, which is underway in our laboratory.

\section{Acknowledgment}

The author is grateful to Mr. Md. Zahid Hossain, M. Phil student, Institute of Biological Science, University of Rajshahi for carefully reading this manuscript. 


\section{References}

1. D. K. Salunkhe and B. B. Desai (CRC Press Inc. Boca Raton, Florida. 1984) pp.77.

2. M. A. Samad and A. H. M. Faruque, Bangladesh Horticult. 4, 1 (1976).

3. S. S. Prasad and A. K. Sinha, Nat. Acad. Sci. Let. 3, 356 (1980).

4. M. F. Mondal, M. A. Rahman, and M. A. J. Pramanik, Bangladesh Horticult. 23, 1 (1995).

5. S. Krishnamurthy and H. Subramanyam, Trop. Sci. 15(2), 167 (1973).

6. B. C. Mazumdar and K. Majumder (Uni. College of Agric. Calcutta University, 2003) pp.108.

7. W. Hortwitz, Official and Tentative Methods of Analysis (Association of the Official Agriculture Chemist, Washington, DC, USA, 1960).

8. AOAC, Official Methods of Analysis, $17^{\text {th }}$ edition (Association of Official Analytical Chemists, Washington, DC, USA, 2002).

9. J. Jayaraman, Laboratory Manual in Biochemistry (Wiley Eastern Ltd. New Delhi, India, 1981) pp. 138.

10. G. L. Miller, Anal. Chem. 31, 426 (1972). http://dx.doi.org/10.1021/ac60147a030

11. M. M. Rahman, M. M. Rahman, N. Absar, and M. A. Ahsan, Bang. J. Sci. Indus. Res. 46, 443 (2011).

12. H. G. Bray and W. V. T. Thorpe, Biochem Anal. 1, 27 (1954). http://dx.doi.org/10.1002/9780470110171.ch2

13. A. Mahadevan and R. Sridhar, Methods of Physiological Plant Pathology, $2^{\text {nd }}$ edition (Sivakasi Publication. Madras, India, 1982).

14. M. A. Hossain, K. Nakamura, and Y. Kimura, Biosci. Biotech. Biochem. 73, 140 (2009). http://dx.doi.org/10.1271/bbb.80561

15. M. A. Hossain, M. M. Rana, Y. Kimura, and H. A. Roslan, BioMed Res. Int. Article ID 232969, 1 (2014). http://dx.doi.org/10.1155/2014/232969

16. M. J. Soule and T. T. Hatton - Proc. Fla. Mango Forum (1955) pp. 16.

17. S. N. Jha, K. Narsaiah, A. D. Sharma, M. Singh, S. Bansal, and R. Kumar, J. Food Sci. Technol. 47, 1 (2009). http://dx.doi.org/10.1007/s13197-010-0004-6

18. A. K. Mattoo and V. V. Modi - Proc. Conf. on Tropical and Subtropical Fruits (London, 1969) pp. 111.

19. A. Payven and J. F. Person, Ann. Chem. (Phys.) 53, 73 (1883).

20. A. A. Klysov, Biochemistry 29, 10577 (1990). http://dx.doi.org/10.1021/bi00499a001

21. G. Vela, M. Leond, H. S. Garcia, and J. De lacruz, J. Hortic, Sci. Biotech. 78, 104107 (2003). http://dx.doi.org/10.1080/14620316.2003.11511573

22. Y. -M. Jiang, Food Chemist. 66, 75(1999). http://dx.doi.org/10.1016/S0308-8146(98)00242-8

23. M. Chisari, R. N. Barbagallo, and G. Spagna, J. Agri. Food Chem. 55, 3469 (2007). http://dx.doi.org/10.1021/jf063402k

24. M. Awad and R. E. Yang, Plant Physiol. 64, 306 (1979). http://dx.doi.org/10.1104/pp.64.2.306

25. E. Pesi, Y. Fuchs, and G. Zauberman, Plant Physiol. 61, 416 (1978). http://dx.doi.org/10.1104/pp.61.3.416

26. A. F. Abu-Sarra and A. A. Abu-Goukh, J. Hort. Sci. 67, 561(1992). http://dx.doi.org/10.1080/00221589.1992.11516284

27. G. E. Hobson, Enzymes and Texture Changes during Ripening, In: J. Friend et al. (Academic Press, London, 1981) pp. 123-132.

28. Y. Selvaraj and R. Kumar, J. Food Sci. Technol. 26, 218 (1989).

29. B. Roe and J. H. Bruemmer, J. Food Sci. 46, 186 (1981). http://dx.doi.org/10.1111/j.1365$\underline{2621.1981 . t b 14560 . x}$

30. K. C. Gross and C. E. Sams, Phytochem. 23, 2457 (1984). http://dx.doi.org/10.1016/S00319422(00)84075-3

31. R. J. Redgwell, L. D. Melton, and D. J. Brasch, Carbohydr. Res. 209, 191 (1991). http://dx.doi.org/10.1016/0008-6215(91)80156-H

32. M. A. Hossain, H. A. Roslan, M. R. Karim, and Y. Kimra, Int. J. Bioinform. Res. Appl. 12(2), 151 (2016), http://dx.doi.org/10.1504/IJBRA.2016.077125 
33. M. A. Hossain and H. A. Roslan, Sci. World J. Article ID 186029, 1 (2014). http://dx.doi.org/10.1155/2014/186029

34. K. M. P. Sethu, T. N. Prabha, and R. N. Tharanathan, Phytochem. 42, 961 (1996). http://dx.doi.org/10.1016/0031-9422(96)00057-X

35. A. E. R. Ahmed and J. M. Labavitch, Plant Physiol. 65, 1014 (1980). http://dx.doi.org/10.1104/pp.65.5.1014

36. H. Nakagawa, N. Enomoto, M. Asakawa, and Y. Uda, Agric. Biol. Chem. 52, 22 (1988).

37. A. Heredia, R. Guillén, A. Jimenéz, and J. Fernándex-Bolanos, Zeitschrift für LebensmittelUntersuchung Forsch. 196, 147 (1993). http://dx.doi.org/10.1007/BF01185575

38. J. K. Burns and E. A. Baldwin, Physiol. Plant. 90, 37 (1994). http://dx.doi.org/10.1111/j.13993054.1994.tb02189.x 